\title{
ІНФРАСТРУКТУРА РИНКУ НЕРУХОМОСТІ ЯК ЧИННИК ЕКОНОМІЧНОЇ ВИЗНАЧЕНОСТІ ТА СТАБІЛЬНОСТІ РИНКУ
}

\author{
Топал Анатолій Анатолійович, \\ керівник Громадської організачіi \\ «Асочіація професійних управляючих нерухомістю», \\ стариий викладач кафедри теоретичної та прикладної економіки \\ ВНЗ «Університет економіки та права «КРОК», \\ ORCID: https://orcid.org/0000-0003-2624-4540,
}

\begin{abstract}
Піта Юрій Аанатолійович, президент «Асоиіації фахівиів з нерухомого майна (рієлторів) Украӥни», старший викладач кафедри теоретичної та прикладної економіки, ВНЗ «Університет економіки та права «КРОК», ORCID: https://orcid.org/0000-0002-2010-8735
\end{abstract}

Анотація. Сучасний ринок нерухомого майна в Україні міг би ефективно виконувати роль стабілізатора національної економіки у кризових умовах. Саме ринок нерухомого майна називають «локомотивом економіки». Макроекономічний вплив ринку нерухомого майна на загальний стан економіки є суттєвим для всіх економічно розвинутих країн. Український ринок нерухомості, ймовірно, не мав би бути винятком. Стабілізаційна функція цього ринку зростає в умовах економічних криз принаймні з двох причин. По-перше, економічні суб'єкти сприймають нерухоме майно як найбільш надійний актив порівняно, наприклад, 3 різними видами фінансових активів. По-друге, саме ринок нерухомого майна стає «потужним магнітом» для інвестицій. Це має забезпечувати зростання кількості робочих місць та розвиток пов'язаних з ринком нерухомого майна галузей. У цьому розділі досліджується проблема вдосконалення інфраструктури ринку й окремих видів підприємницької діяльності для забезпечення його стабільності й органічної взаємодії 3 іншими галузевими ринками.

Ключові слова: ринок нерухомості, підприємництво на ринку нерухомості, рієлторство, оціночна діяльність, управління нерухомістю, дивелоперська діяльність.

Актуальність дослідження національного ринку нерухомості 3 позицій удосконалення підприємницької інфраструктури цього ринку не викликає жодних сумнівів. Адже цей ринок на всіх етапах новітньої української економічної історії забезпечував створення відносно великої частки ВВП країни та сотні тисяч робочих місць. Інформація про частку ринку нерухомості у створеному ВВП країни подана на рис. 1. 


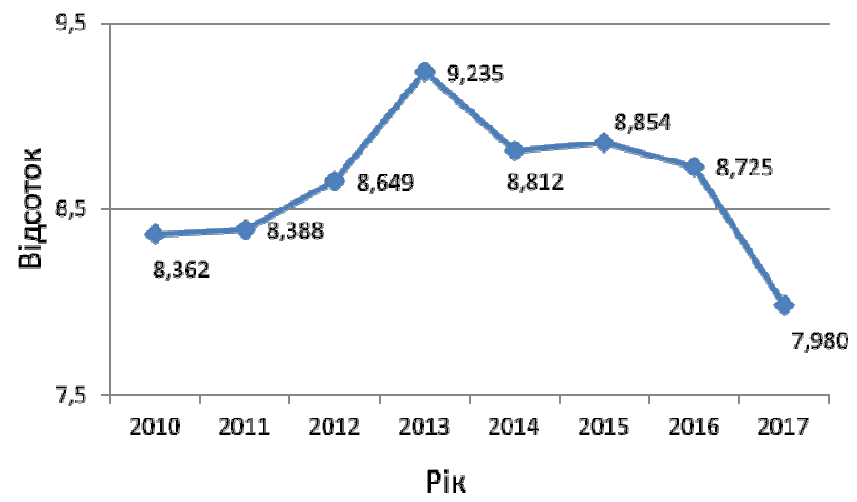

Рис. 1. Динаміка частки «Операцій з нерухомим майном» у створенні ВВП України

Джерело: створено авторами на основі [1].

Інформація, подана на рис. 1, свідчить про те, що частка діяльності, означеної як «Операції з нерухомим майном» у ВВП країни, є значною. Вона $є$ співставною, наприклад, з частками таких сфер, як освіта, медицина тощо. Завдяки ринку нерухомого майна зазвичай створювалася значна кількість робочих місць в українській економіці. Динаміка кількості робочих місць, що забезпечувалися завдяки функціонуванню ринку нерухомості, ілюстрована на рис. 2.

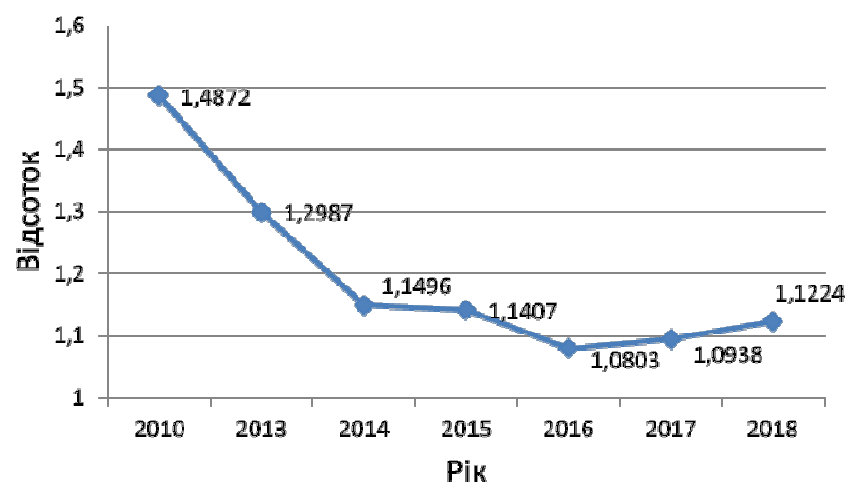

Рис.2. Динаміка частки зайнятих осіб у сфері

«Операції 3 нерухомим майном» в Україні у 2010 - 2018 рp.

Джерело: створено авторами на основі [1].

Інформація про частку зайнятих у сфері «Операції з нерухомим майном» на рис. 2 свідчить про те, що, починаючи з 2016 року, 
почалася позитивна динаміка зростання частки зайнятих осіб. Вона впритул наблизилася до рівня 2014 року, коли розпочався спад у зв'язку з російсько-українською війною.

Проблеми організації та функціонування ринку нерухомого майна $є$ предметом багатьох досліджень фахівців та експертів цього ринку [2-4]. Більшість сучасних досліджень ринку нерухомості присвячені з'ясуванню трендів зміни цін на нерухомість та оцінюванню чинників, які впливають на динаміку цін. Але $\epsilon$ й багато досліджень, присвячених більш фундаментальним питанням, а саме: зв'язку між загальною економічною кризою та станом ринку нерухомості, способам подолання наслідків кризи з використанням ринку нерухомості.

Вітчизняні дослідники ринку нерухомості [5-7] зосереджують свою увагу не лише на тенденціях зміни цін на нерухомість, а й на осмисленні ролі цього ринку в стабілізації національної економіки. Зокрема, досліджується зв'язок між розвитком ринку нерухомості, 3 одного боку, та розвитком фінансового ринку - з іншого, між динамікою реальних доходів українців та масштабами придбання житлової, комерційної тощо нерухомості.

І вітчизняних, й іноземних дослідників з 2020 р. цікавить оцінювання та прогнозування впливу на еволюцію ринку нерухомості надзвичайної ситуації - пандемії Covid-19 [8].

Сучасний ринок нерухомого майна України формується представниками кількох видів підприємницької діяльності та передбачає їх взаємодію. Необхідність такого об'єднання зумовлюється складністю самої сфери економіки нерухомості, урізноманітненням структури попиту на нерухоме майно та зростаючими потребами споживачів. 3 огляду на все зазначене, ми робимо припущення про доцільність застосування в аналізі ринку та власне в практичній діяльності терміну «інфраструктура ринку нерухомості».

Як і будь-яка інфраструктура інших ринків, інфраструктура ринку нерухомості має охоплювати окремі сегменти ринку, репрезентовані підприємцями 3 різними компетентностями. Попри відмінність компетентностей, всі вони пов'язані зі створенням послуг, якими супроводжується купівля-продаж, відтворення та використання нерухомого майна. Наше уявлення про інфраструктуру ринку нерухомості ілюстровано схемою (рис. 3).

На рис. 3 ілюстровано такі ідеї щодо інфраструктури ринку нерухомості загалом та підприємництва на ринку нерухомості зокрема:

- інфраструктура ринку нерухомості охоплює так зване «ядро», що складається з підприємців пов' язаних між собою видів діяльності, а саме: рієлтерів, оцінщиків майна, управляючих майном, девелоперів;

- окрім «ядра», функціонує елемент інфраструктури у вигляді так званого «захисного поля» у складі п'ятьох елементів, а саме: національних 
регуляторів (органів державної влади), банків, пов'язаних з іпотечним кредитуванням, будівельних (ремонтних) організацій, страховиків у сфері нерухомості та консалтингових компаній;

- об’єднані ринком нерухомого майна, підприємства, що формують «ядро» інфраструктури ринку, виконують хоча й пов’язані, але особливі функції. Тому йдеться про чотири сегменти «ядра», а саме: рієлторів, оцінщиків, управляючих нерухомістю та девелоперів;

- «захисний пояс» інфраструктури ринку нерухомості покликаний формувати його стабілізуюче - ефективне та безпечне - середовище, пов'язане з законодавством (правилами діяльності), формуванням джерел для інвестування, відтворенням об'єктів нерухомості, страхуванням та інтелектуальним - аналіз та обгрунтування рішень - забезпеченням.

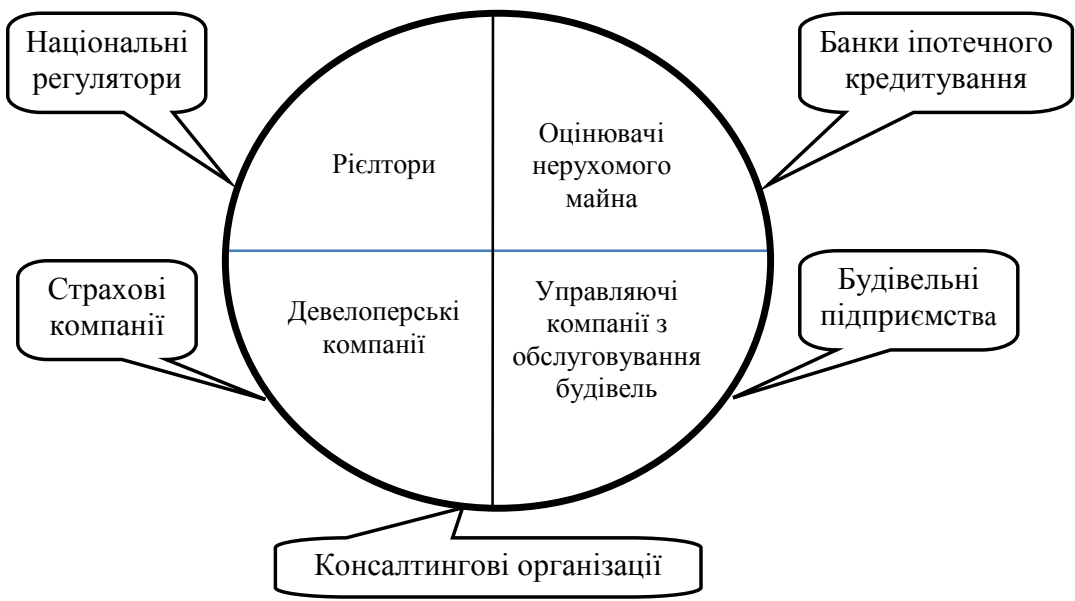

Рис. 3. Інфраструктура ринку нерухомості та відповідні форми підприсмницької діяльності

Джерело: створено авторами самостійно.

Підприємництво в кожному з сегментів «ядра» інфраструктури ринку нерухомості - в рієлторстві, оцінці, управлінні будівель, девелоперстві - має в Україні власні організаційні, правові особливості та певні проблеми. Спробуємо охарактеризувати найбільш визначальні особливості та актуальні проблеми кожного з них.

Осердя підприємницької діяльності на українському ринку нерухомості формує рієлторство. Воно вже виокремилося як специфічний функціональний напрямок та як вид діяльності.

У суб’єктів підприємницької рієлторської діяльності формуються особливі стосунки з національними регуляторами. Ці стосунки є достатньо контроверсійними. Зокрема, існує невідповідність між офіційним 
тлумаченням змісту поняття «рієлторська діяльність» та сутністю цієї діяльності з позицій операторів ринку нерухомості.

За Класифікатором видів економічної діяльності [9] (секція I), виокремлено діяльність таких економічних суб' єктів: «орендодавців, агентів i/aбо посередників 3 продажу або купівлі, надання в оренду нерухомого майна, надання інших послуг відносно нерухомого майна, таких як оцінювання об'єктів нерухомості або дії в якості агентів рахунків депонування». У документі зазначено, що ця діяльність «може здійснюватися відносно власної або орендованої нерухомості та може виконуватися на основі фіксованих виплат або на основі контракту». Йдеться також про діяльність з будівництва конструкцій у поєднанні 3 набуттям прав власності або оренди цих конструкцій. Важливо також те, що в документі виокремлюється діяльність «менеджерів 3 управління нерухомим майном». Предмет діяльності останніх - це три групи операції 3 нерухомим майном, що охоплюють:

- купівлю та продаж власного нерухомого майна;

- надання в оренду;

- надання в експлуатацію власного чи орендованого нерухомого майна.

В аналізованому документі йдеться про таку форму підприємництва, як агентства нерухомості, які, за уявленнями творців цього документа, охоплюють таку діяльність:

- посередницькі послуги з купівлі, продажу або надання в оренду нерухомого майна на підставі фіксованих виплат або на контрактній основі;

- надання за винагороду або на основі контракту консультаційних послуг і послуг з оцінювання нерухомого майна, які пов'язані з його купівлею, продажем або наданням в оренду;

- послуги агентів умовного депонування.

Саме таке тлумачення діяльності рієлторів призводить до конфлікту між суміжними професіями - рієлторами, агентами 3 нерухомості, оцінювачами та управителями нерухомого майна.

Намагання прийняти закони [10] без узгодження інтересів та без необхідної комунікації з професійною спільнотою рієлторів, замість стабілізації та визначеності, породжує дестабілізацію та невизначеність.

Значна частина угод з нерухомим майном відбувається з залученням рієлторів або агентів з нерухомості. Так, за даними Асоціації професійних управляючих нерухомістю, спостерігалася така динаміка кількості угод за участі професійних рієлторів (у \% до загальної кількості угод на ринку нерухомості):

$$
\begin{aligned}
& 2001 \text { - } 2008 \text { pp. }-75-80 \% \text {; } \\
& 2009 \text { p. - 60-65\%; } \\
& 2010 \text { p. - близько 50\%; } \\
& 2011 \text { p. - 40\%; }
\end{aligned}
$$


2012 р. - близько $37 \%$ [11];

$2013-2018$ pp. $-60-65 \%$ [12].

Аналіз динаміки угод 3 нерухомістю, за участі професійних рієлторів, засвідчує коливальний характер змін. До певної межі прослідковується тенденція скорочення цієї частки. Зазвичай це відбувається в періоди економічних рецесій та збільшення недовіри до органів публічної влади. І навпаки, частка таких угод зростає в періоди більшої економічної стабільності та довіри до дій влади.

Важливим аспектом організації підприємницької діяльності на ринку нерухомості є ставлення споживачів рієлторських послуг до компетентності професіоналів ринку нерухомості й очікування споживачів щодо результатів діяльності. 3 опитувань споживачів виявилося таке: iз $100 \%$ потенційних покупців та продавців нерухомості тільки $11 \%$ категорично відмовляються від співпраці з рієлторами, $15 \%$ вже визначилися, з яким рієлтором будуть працювати, 16\% мають бажання працювати з рієлтором, але не знають, до кого звернутися [12].

Ставлення клієнтів до рієлторства є достатньо контроверсійним. Адже 31\% клієнтів фактично готові працювати 3 рієлтором, але не розуміють суті рієлторської послуги та не знають ії вартості. А 23\% клієнтів готові працювати з рієлтором, але остерігаються низької якості рієлторської послуги. Лише 4\% споживачів мають сумнів щодо необхідності використання рієлторської послуги [13]. Аналітики ринку нерухомості фіксують значний дефіцит таких послуг 3 ознаками високої якості, прозорості та зрозумілості для споживача змісту діяльності рієлтора.

3 аналізу статистики опитувань споживачів на ринку нерухомості випливає висновок про брак довіри у відносинах між фахівцями ринку та клієнтами, необізнаність клієнтів у перевагах співпраці з фахівцями ринку та недостатність фахівців найвищої кваліфікації.

Рієлторська діяльність, як окремий вид підприємництва, має об'єктивні економічні та соціальні підстави для майбутнього розвитку. Де-факто, сформувався окремий субринок послуг - ринок рієлторської послуги. Де-юре, ще триває легалізація цього ринку. Чинна законодавча база для функціонування українського ринку рієлторських послуг охоплює такі кодекси: Цивільний кодекс України, Господарський кодекс України, Податковий кодекс України. Ї̈̈ складниками є окремі закони, а саме: Закон України «Про запобігання та протидію легалізації (відмиванню) доходів, одержаних злочинним шляхом, фінансуванню тероризму та фінансуванню розповсюдження зброї масового знищення», Закон України «Про захист прав споживачів», Закон України «Про рекламу». Важливим складником законодавчої бази $є$ й Наказ ДП «УкрНДНЦ» Національного органу стандартизації №40 від 27 лютого 2019 р. «Про прийняття національного стандарту ДСТЕУ ЕN 15733:2019 
«Послуги агентів 3 нерухомості. Вимоги до надання послуг агентів 3 нерухомості» [14].

На жаль, спеціального закону про регулювання реєлторської діяльності в Україні не існує. Вже багато років точиться дискусія між прихильниками прийняття такого закону та прихильниками ідеї непотрібності такого спеціального законодавчого регулювання. Обидві сторони дискусії мають аргументи на обгрунтування власного підходу.

Основна проблема регулювання ринку нерухомості полягає у відсутності визначеності саме в механізмах регулювання. Йдеться про вибір між двома альтернативами, а саме: між «жорстким» державним регулюванням та «м'яким» регулюванням 3 передачею повноважень організаціям саморегулювання. На нашу думку, на початковому етапі упорядкування діяльності ринку рієлторських послуг має існувати «змішане регулювання» держави та громадських (самоврядних) професійних організацій. Критерієм такого поєднання має стати сприяння визначеності на ринку та його розвитку. В подальшому має реалізуватися вектор у бік більшого саморегулювання ринку.

За даними, зібраними органами державної статистики, за участі громадських об'єднань рієлторів та експертів ринку, кількість учасників ринку рієлторської послуги коливається віл 50 до 65 тис. осіб [1]. Більш точну оцінку кількості учасників ринку для забезпечення вищого рівня визначеності операцій надати неможливо з кількох причин:

- існує значна кількість підприємств у вигляді так званих ФОПів, які вже припинили або припиняють свою діяльність, але це ще не відбулося офіційно;

- значна кількість підприємців не легалізує своєї діяльності;

- не існує єдиного реєстру учасників ринку рієлторських послуг.

Законодавче визнання рієлторських послуг, як окремого продукту піприємницької діяльності, залишається незавершеним. Це формує одну з основних причин економічної невизначеності на цьому ринку. Саме так вважає український дослідник Міненко М. А. Він, зокрема, фіксує такі конкретні причини невизначеності ринку, як часткове відсторонення держави від вирішення питання легітимізації рієлторства як послуги, відсутність Закону України «Про рієлторську (брокерську) діяльність», що сприяв би формуванню прозорого правового поля [15].

Важлива роль у функціонуванні достатньо «молодого» українського ринку нерухомості, що перебуває в стані високої невизначеності, належить громадським об'єднанням професіоналів ринку. Об'єднання лобіюють, організовують, виступають із законодавчими ініціативами, намагаються робити діяльність прозорою, захищають інтереси учасників ринку. Такими, зокрема, є Асоціація фахівців 3 нерухомого майна (рієлторів) України, Спілка фахівців з нерухомого майна України, Рієлторська палата України, Гільдія рієлторів України. Але демократичні 
принципи функціонування громадських об'єднань іноді заважають формуванню спільного бачення проблем, а також розробці однакових підходів до організації відносин з органами державної влади тощо. Це може ставати причиною уповільненого формування правового поля та правового визнання рієлторства як офіційно-стандартизованої професії.

На початку 2020-х рр. на заваді розвитку рієлторства, як професії та різновиду підприємницької діяльності, постають невирішені проблеми системних зловживань з боку представників влади. Йдеться, зокрема, й про представників депутатського корпусу та окремих чиновників, що намагаються «зарегулювати» ринок 3 метою створення різних «схем збирання коштів» 3 усіх учасників ринку. Правова невизначеність стає однією з головних причин низького рівня довіри споживача послуг до фахівців ринку нерухомості. Адже значною мірою через дії влади рієлтор, як дійова особа ринку, ще не має зрозумілого для споживача послуг загальнодержавного професійно-правового статусу.

Рієлторська спільнота України здобуває свій статус та довіру українських громадян в умовах економічної невизначеності різними шляхами. Важливими здобутками професійної спільноти є такі дії й такі результати цих дій:

- постійна участь у міжнародних конгресах Національної Асоціації Рієлторів США, Міжнародної федерації з нерухомості (FIABCI), Міжнародної асоціації менеджменту нерухомості;

- постійне представництво фахових об'єднань у роботі освітніх програм Свропейського Фонду освіти;

- упровадження на рівні Державного Стандарту України європейської норми (EN) Стандарту «Послуги агентів 3 нерухомості. Вимоги до надання послуг агентів з нерухомості»;

- участь у робочих групах 3 розробки проєкту Закону про врегулювання рієлторської (брокерської) діяльності;

- участь у роботі Міжгалузевої Кваліфікаційної Ради з розробки професійних стандартів у сфері менеджменту нерухомості, благоустрою та житлово-комунального господарства (ЖКГ) щодо розробки професійних стандартів «Рієлтор» та «Агент з нерухомості»;

- участь у створенні магістерських програм, у межах яких реалізується спеціалізація, що можна визначити як «фахівець ринку нерухомого майна»;

- участь у формуванні загальної системи освітньо-професійної підготовки спеціалістів ринку рієлторської послуги за єдиним державним стандартом.

Першочерговими для остаточної легітимізації рієлторства як окремої професії та виду підприємницької діяльності, на наш погляд, мають бути такі кроки:

- створення єдиного національного керівного органу на засадах саморегулювання, до функцій якого належатиме таке: представництво 
інтересів учасників ринку у взаєминах 3 державними інституціями та іншими зацікавленими суб' єктами відносин, формування реєстру офіційних рієлторів України, участь в атестації та сертифікації професіоналів ринку, розробка стандартів якості наданих послуг та організація заходів з реагування професійної спільноти на їх порушення;

- затвердження єдиних стандартизованих підходів до рієлторської діяльності як особливого виду підприємництва;

- подальше впровадження ДСТУ в частині «Послуги агентів 3 нерухомості. Вимоги до надання послуг агентів 3 нерухомості»;

- розробка Професійного Стандарту «Рієлтор» та «Агент 3 нерухомості» й затвердження на його основі освітньо-професійних програм підготовки бакалаврів та магістрів за відповідним фахом;

- імплементація до Державного класифікатора професій і Довідника кваліфікаційних характеристик професій необхідної та узгодженої інформації щодо спеціальності «Рієлтор» та «Агент з нерухомості»;

- створення системи підтвердження кваліфікацій «Рієлтор» та «Агент з нерухомості» за міжнародними вимогами.

Підприємництво в оціночній діяльності України характеризується низкою організаційних особливостей та невирішених проблем.

Оцінювачем в Україні може бути фізична особа (громадянин України, іноземець або особа без громадянства), яка має базову або повну вищу освіту. Згадана особа має пройти навчання у навчальному закладі, який уклав відповідну угоду про навчання оцінювачів з Фондом державного майна України.

Визнання необхідності спеціальної вищої освіти для оцінювачів $€$ значною перевагою та здобутком у цій сфері діяльності. Крім іншого, фахівець з оцінювання майна повинен здійснити стажування протягом одного року в складі організації, що займається оціночною діяльністю, за відповідними вузькими спеціалізаціями, скласти кваліфікаційний іспит та отримати кваліфікаційне свідоцтво оцінювача відповідно до вимог законодавства України [16].

Позитивом в організації оціночної діяльності $є$ також існування вимог і порядку включення інформації про оцінювачів та суб'єктів оціночної діяльності до Державного реєстру. Законодавство визначає й правові засади та процедури збирання, нагромадження, обробки й отримання інформації щодо оціночної діяльності. Згідно зі згаданим Державним реєстром на червень 2020 р. в Україні офіційно зареєстровано 13125 осіб.

Професійні оцінювачі об'єднані у громадську організацію «Всеукраїнська Асоціація Фахівців Оцінки», яка виконує функцію представництва інтересів підприємців-оцінювачів. Ця організація забезпечує ідентифікацію й оприлюднення проблем, які обмежують та 
гальмують оціночну діяльність. Зрозуміло, що тривале ігнорування цих проблем спричиняє зростання невизначеності в оціночній сфері.

До проблем в організації оціночної діяльності, консервація яких збільшує невизначеність у цій сфері, належить таке:

- відсутність новітньої державної політики в галузі оціночної діяльності з чітко окресленими новими вимогами до професії оцінювачів та до оціночної діяльності загалом;

- брак правових основ поєднання державного регулювання та саморегулювання оціночної діяльності, а також делегування окремих функцій держави професійним саморегульованим організаціям;

- складність для розуміння, тлумачення і застосування чинного Закону України «Про оцінку майна, майнових прав та професійну оціночну діяльність в Україні». Йдеться передусім про права й обов'язки держави, оціночної спільноти, громадськості та кінцевих споживачів оціночних послуг. А також про права та обов'язки щодо ціноутворення й ініціатив регулювання діяльності.

Громадська організація «Всеукраїнська Асоціація Фахівців Оцінки» усвідомлює необхідність створення Концепції розвитку оціночної діяльності у 2020-х рр. У ній мали б знайти віддзеркалення минулі здобутки в організації оцінки майна, прогнози розвитку оціночної діяльності та проблеми, які не знаходять вирішення. Проєкт такої Концепції наразі створюється.

Розпочата реформа житлово-комунального господарства України в 2010-х рр. зробила актуальною нову для нашої країни професію управляючого будовами, зокрема багатоквартирними будинками. Потреба у фахівцях 3 управління нерухомістю сформувалася під впливом розширення права співвласників багатоквартирних будинків на розпорядження спільним майном. Адже мешканці багатоквартирних будинків отримали право самостійно обирати одну 3 трьох форм управління [17]. Йдеться, зокрема, про такі форми:

- створення об'єднання співвласників багатоквартирного будинку (ОСББ), що спонукає брати на себе відповідальність мешканців власного будинку;

- залучення до управління будинком управителя, якого співвласники обирають самостійно, або у разі неприйняття рішення про форму управління управителя на конкурсній основі призначає міська влада;

- самостійне управління багатоквартирним будинком, не створюючи ОСББ та не залучаючи управителя.

Надання послуги з управління багатоквартирним будинком, що здійснюється управителем на підставі договору про надання послуг 3 управління, укладається відповідно до вже згаданого Закону [17] та Закону України «Про житлово-комунальні послуги» [18]. 
У сучасному тлумаченні, компетентності підприємців, залучених до управління багатоквартирною нерухомістю, передбачають здатність виконання таких функцій:

- утримання спільного майна багатоквартирного будинку, включно з внутрішніми будинковими приміщеннями та прибудинковими територіями;

- виконання санітарно-технічних робіт;

- обслуговування внутрішніх будинкових систем;

- придбання електричної та теплової енергії для забезпечення функціонування спільного майна багатоквартирного будинку;

- поточний ремонт спільного майна багатоквартирного будинку.

Очевидно, що наведений перелік функцій охоплює лише незначну частину передусім лише технічних вимог до результатів підприємницької діяльності у цій сфері. Тому він $є$ неповним. Зокрема, ним не охоплено економічних та комунікаційних функцій, відповідно, компетентностей, що їх повинен мати управлінець. У складі останніх, на наш погляд, мали б бути зазначені такі функції:

- отимізація витрат на утримання, ремонт, модернізацію споруди з урахуванням іiї технологічного стану;

- моніторинг якості послуг та цін на послуги виконавців ремонтних, відновлювальних тощо робіт;

- укладання договорів на виконання робіт з будівельними та ремонтними організаціями і контроль за їх виконанням;

- розробка бізнес-проєктів та знаходження зовнішніх джерел фінансування для покращення стану споруди, збереження довкілля, підвищення комфортності проживання тощо;

- комунікація 3 органами місцевої та центральної влади у випадках непередбачуваних ситуацій, техногенних загроз тощо; майна тощо.

- участь в укладанні договорів зі страхування будівель, споруд,

На наш погляд, підприємницька діяльність у сфері управління спорудами характеризується надзвичайно високою невизначеністю порівняно з іншими видами діяльності на ринку нерухомості. Крім іншого, це спричиняється й відсутністю традиції ведення бізнесу у цій сфері, відповідно, браком досвіду українських підприємців у цій сфері.

У XXI ст. на ринку нерухомості України започатковано й активно розвивається новий вид підприємництва - девелоперство.

Девелоперська компанія - організація, що отримує прибуток від створення та розвитку об'єктів нерухомості, збільшуючи їх вартість. У широкому сенсі, це - юридична або фізична особа, що забезпечує просування і реалізацію бізнесового проєкту в сфері нерухомості.

У 2020 р. в Україні зареєстровано близько 400 девелоперських компаній. Експерти стверджують, що майже 90\% послуг у сфері 
девелопменту виконують вітчизняні компанії. Частка іноземних компаній $\epsilon$ незначною. Це пов'язано з тим, що українські девелоперські компанії мають певні переваги на ринку. Зокрема, ті, що пов'язані з використанням земельних ділянок, 3 кращою адаптованістю до особливих умов української економіки.

Традиційно, до функцій девелоперських компаній на ринку нерухомості належать:

- оформлення в місцевих органах влади дозвільної документації на будівництво (розпорядження щодо проєкту, інвестиційний контракт, технічний паспорт, отримання узгоджень та дозволів);

- управління проєктуванням (формування групи проєктувальників, управління підготовкою ескізного проєкту та техніко-економічного обгрунтування (ТЕO);

- управління будівництвом (проведення тендерів серед будівельних підрядників, управління будівництвом, здача об'єкта в експлуатацію);

- залучення зовнішніх кредитних та інвестиційних коштів (розробка інвестиційної стратегії проєкту, структури фінансування проєкту, договорів для підписання між компанією та фінансовими установами);

- просування об'єктів нерухомості (розробка маркетингової концепції та стратегії, розміщення реклами, розробка типового договору оренди або продажу й проведення переговорів 3 потенційними клієнтами).

Девелоперська компанія може виконувати як роль інвестора у девелоперському проєкті, так і роль посередника, а також організатора інвестиційного проєкту в сфері нерухомості.

Девелоперська діяльність $є$ особливим підприємництвом, пов'язаним з обслуговуванням інвестиційних проєктів у сфері нерухомості. Беручи на себе відповідальність за терміни та якість виконання проєкту, девелопери одночасно беруть на себе й частину проєктних ризиків. Однією з проблем підприємницької девелоперської діяльності в Україні $є$ необгрунтоване перекладання цих ризиків девелоперами на інших економічних суб'єктів та намагання уникнути відповідальності.

До інфраструктури ринку нерухомості, як ілюстровано на рис. 3, належать ті підприємства й організації, які не формують власне ринок нерухомості, але створюють зовнішне середовище його функціонування. Це зовнішнє середовище формується за участі: національних регуляторів ринку нерухомості, фінансово-кредитних установ (зокрема, банків іпотечного кредитування), будівельних підприємств, консалтингових підприємств, страхових компаній.

Національні регулятори ринку нерухомості - це передусім органи державної влади у складі: Міністерства фінансів України (зокрема, в частині фінансового моніторингу), Фонду державного майна України, Міністерства розвитку громад та територій України. Спеціального дослідження потребує питання приналежності до національних регуляторів 
загальноукраїнських професійних асоціацій (об’єднань). До таких, зокрема, належать уже згадувані нами громадські організації в особі Асоціації фахівців з нерухомості (рієлторів) України (АФНУ); Спілки фахівців 3 нерухомого майна України (СФНУ); Українського товариства оцінювачів (УТО), Конфедерації будівельників України (КБУ), Будівельної палати України.

Фінансово-кредитні організації в особі банків іпотечного кредитування та інших комерційних банків $є$ причетними до функціонування ринку нерухомості. Адже вони надають фінансові ресурси, яких тимчасово бракує учасникам ринку. Активно займаються іпотечним кредитуванням такі українські банки, як ПАТ «Кредобанк», Укргазбанк, Правекс-банк, Ощадбанк, Приватбанк.

Іпотечне кредитування в Україні намагаються відродити за рахунок зниження відсоткової ставки за користування кредитними коштами. При цьому змінилися вимоги до позичальників, а саме до підтвердженого офіційного доходу позичальника. Банки більш ретельно перевіряють інформацію про доходи. Найбільшою проблемою кредитування є недовіра позичальників саме до іпотечного кредитування. Вона спричинена негативним досвідом позичальників періоду «іпотечного буму» $2006-2008$ pp.

Будівельні підприємства створюють ту частину зовнішнього середовища ринку нерухомості, яка пов'язана 3 виникненням нових об'єктів цього ринку та їх відтворенням у належному стані (ремонтуванням). Існують певні особливості взаємин безпосередніх учасників ринку з будівельними організаціями. Загалом, ці взаємини $\epsilon$ конструктивними. Співпраця між фахівцями ринку нерухомості й забудовниками активно розвивається. Співпраця здійснюється здебільшого у таких формах:

- забудовники, маючи угоду з певним агентством нерухомості, сплачують йому комісію за просування та продаж об’єктів нерухомого майна покупцеві;

- забудовники співпрацюють з усіма рієлторами, які рекомендують та продають об'єкти, створені забудовником, на засадах так званої публічної оферти співпраці для всіх рієлторів.

Проблема співпраці забудовників з агентами ринку нерухомості пов'язана передусім з тим, що деякі забудовники ідентифікують рієлторів як конкурентів. Ідеться про конкуренцію та нібито «конфлікт інтересів» відділів продажів забудовника і рієлторів. Таке тлумачення «конфлікту інтересів» $€$ хибним хоча б тому, що у відділу продажів $\epsilon$ функція реклами об'єкту. Останньої не має рієлтор, який забезпечує комплексний супровід руху об'єкту нерухомості від забудовника до покупця.

Ще один сегмент інфраструктури ринку нерухомості консалтингові підприємства - можуть бути причетними до створення 
проєктів оновлення будівель та споруд, до їх перепрофілювання, до використання інноваційних технологій, до пошуку інвесторів у країні та за їі межами.

Страхові компанії $є$ компонентом інфраструктури будь-якої підприємницької діяльності, включно з діяльністю на ринку нерухомості. В українських умовах роль страхових компаній мала б бути більш масштабною та краще регламентованою. Це пояснюється значною амортизацією нерухомості, техногенними загрозами, пов'язаними 3 незадовільним станом комунального господарства, з браком необхідних стандартів у будівництві та обслуговуванні споруд.

На ринку нерухомості існує декілька видів страхування. Найбільш поширеними $є$ класичне страхування об'єкту нерухомості як майна та страхування прав на нерухомість - так зване титульне страхування. Більш поширеним в Україні є перший вид страхування. Розвиток послуг страхування нерухомості стримується насамперед алгоритмом ціноутворення. Ціна страхової послуги визначається як певний відсоток від вартості об'єкту, що сплачується щорічно. По-друге, існує дуже складна процедура отримання страхового відшкодування при настанні страхового випадку, що розширює межі економічної невизначеності.

\section{Висновки:}

3 аналізу інфраструктури ринку нерухомості України та підприємництва, пов'язаного з цим ринком, робимо такі узагальнення.

Український ринок нерухомості має значний потенціал розвитку та позитивного впливу на стабілізацію всієї національної економіки. Ринок створює сотні тисяч робочих місць і формує помітну частину доданої вартості, репрезентованої у ВВП країни.

Стабілізаційний потенціал українського ринку нерухомості реалізується неповно. Це стосується всіх складників ринку та усіх видів підприємницької діяльності, що формують передусім «ядро» інфраструктури ринку. Йдеться про такі види підприємництва, як рієлторство, оціночна діяльність, управління нерухомістю, девелоперство.

Кожний вид підприємництва на ринку нерухомості має особливі проблеми діяльності, здатні посилювати економічну невизначеність. Але $є$ принаймні дві загальні для всіх сегментів ринку проблеми. Периа пов'язана 3 незавершеністю й недосконалістю законодавчої бази щодо діяльності фахівців ринку та їх взаємин 3 органами державної влади. Друга стосується професійної самоорганізації ринку, здійснюваної громадськими самоврядними професійними організаціями.

Українські громадські професійні самоврядні організації покликані сприяти вирішенню низки першочергових проблем функціонування ринку нерухомості, а саме:

- створенню та лобіюванню необхідної для стабілізації ринку нерухомості нормативної бази; 
- ідентифікації професійних стандартів діяльності на ринку та контролю за їх дотриманням;

- сприяння формуванню системи професійної освіти та системи перекваліфікації фахівців ринку нерухомості;

- налагодженню ефективної комунікації між органами державної влади (національними регуляторами) з підприємцями, з одного боку, та між підприємцями та споживачами послуг - 3 іншого.

\section{Лimepamypa:}

1. Статистичний щорічник України. URL : http://www.ukrstat. gov.ua/druk/publicat/kat_u/2019/zb/11/zb_yearbook_2018.pdf.

2. Amadeo K. Is the Real Estate Market Going to Crash? URL : https://www.thebalance.com/is-the-real-estate-market-going-to-crash-4153139.

3. Real Estate in a Digital Age 2019 Report. URL : https://www.nar. realtor/research-and-statistics/research-reports/real-estate-in-a-digital-age.

4. Lawrence Y. Housing Demand over the Next Decade. National association of realtors. The Economists' Outlook Blog. 2017. URL : http://economistsoutlook.blogs.realtor.org/2017/03/02/housing-demandover-the-next-decade/.

5. Возняк Г. В. Сучасні механізми фінансування будівництва житла в Україні: проблеми та шляхи вирішення. Бізнес Інформ. 2019. №8. C. 111-116. URL : https://doi.org/10.32983/2222-4459-2019-8-111-116.

6. Кривов'язюк I. В., Свчук А. В. Тенденції розвитку інвестиційно привабливих ринків нерухомості країн Свропи. URL : http://www.vestnikeconom.mgu.od.ua/journal/2019/35-2019/5.pdf.

7. Галаган Д. В. Ринок нерухомості як різновид інвестиційного ринку. URL : http://irbis-nbuv.gov.ua/cgibin/irbis64r_81/cgiirbis_64.exe?C $21 \mathrm{COM}=2 \& \mathrm{I} 21 \mathrm{DBN}=\mathrm{UJRN} \& \mathrm{P} 21 \mathrm{DBN}=\mathrm{UJRN} \& Z 21 \mathrm{ID}=\& \mathrm{IMAGE}$ FILE_ DOWNLOAD=1\&Image_file_name=PDF/ipd_2010_9_7pdf.

8. 5 Indicators To Watch In The Housing Market Recovery From The Coronavirus. URL : https://www.forbes.com/sites/dimawilliams/2020/ 05/15/five-indicators-to-watch-in-the-housing-market-recovery-from-thecoronavirus/-247420145f06.

9. Національний класифікатор України, класифікація видів економічної діяльності. Державний комітет України з питань технічного регулювання та споживчої політики. URL : https://zakon.rada.gov.ua/ rada/show/vb457609-10\#Text.

10. Про рієлторську діяльність в Україні : Проєкт Закону України від 09.09.2020 p. №3618. URL : http://w1.c1.rada.gov.ua/pls/ zweb2/webproc4_1?pf3511=69071.

11. Топал А. Ремісництво - загроза фаху: матеріали Національного форуму «Нерухомість України». Київ, 6-7 груд. 2012 р. 
12. Громадська організація «Асоціація професійних управляючих нерухомістю». URL : https://apun-ua.est.ua/info/.

13. Міненко М. А. Ріелторство в Україні. Державне управління: удосконалення та розвиток. №4. 2013. URL : http://www.dy.nayka.com.ua/ ?op $=1 \& \mathrm{z}=566$.

14. Про прийняття національного стандарту ДСТЕУ ЕN 15733:2019 «Послуги агентів 3 нерухомості. Вимоги до надання послуг агентів 3 нерухомості : Наказ ДП «УкрНДНЦ» Національного органу стандартизації №40 від 27 лютого 2019 p. URL : http://uas.org.ua/wp-content/uploads/ 2019/03/N40_2019-02-27.rtf.

15. Міненко М. А. Ріелторство в Україні. Державне управління: удосконалення та розвиток. №4. 2013. URL : http://www.dy.nayka.com.ua/ ?op $=1 \& \mathrm{z}=566$.

16. Про оцінку майна, майнових прав та професійну оціночну діяльність в Україні : Закон України від 12.07.2001 р. №2658-III. URL : https://zakon.rada.gov.ua/laws/show/2658-14\#Text.

17. Про особливості здійснення права власності у багатоквартирному будинку : Закон України редакція від 10.06.2018 р. №2189-VIII. URL : https://zakon.rada.gov.ua/laws/show/417-19.

18. Про житлово-комунальні послуги : Закон України від 09.11.2017 p. №2189-VIII. URL : https://zakon.rada.gov.ua/laws/show/ 2189-19\#Text. 